\title{
Reduced Pericellular Sensitivity to IGF-I in Fibroblasts From Girls With Turner Syndrome: A Mechanism to Impair Clinical Responses to GH
}

MELISSA WESTWOOD, SHAHIN H. TAJBAKHSH, KIRK W. SIDDALS, ANDREW J. WHATMORE, AND PETER E. CLAYTON

Maternal and Fetal Health Research Centre [M.W.], Endocrinology [S.H.T., A.J.W., P.E.C.], and Imaging, Genomics and Proteomics

[K.W.S.], University of Manchester, Manchester M13 9WL, United Kingdom

\begin{abstract}
Girls with Turner syndrome (TS) are treated with supraphysiological doses of growth hormone $(\mathrm{GH})$ to improve final height; however in some girls, the growth response can be poor. This may reflect aberrations in GH and/or IGF-I actions at the cellular level, and thus this study compared the response of skin fibroblasts from normal children $(n=5)$ and girls with TS $(n=8)$ to GH, IGF-I, or a combination, by assessing the IGF binding protein (IGFBP) profile of conditioned medium harvested over $7 \mathrm{~d}$. The two cell types had a comparable IGFBP profile; IGFBP-3 and IGFBP-4 were the most abundant species. TS fibroblasts produced more IGFBP-3 (d 7, $51.4 \pm 45 \mathrm{ng} / \mathrm{mL}$ versus $20 \pm 22 \mathrm{ng} / \mathrm{mL} ; p<0.05)$ than control cells; levels of IGFBP-4 were similar $(21 \pm 12 \mathrm{ng} / \mathrm{mL}$ versus $30 \pm$ $21 \mathrm{ng} / \mathrm{mL}$ ). GH did not influence IGFBP production. IGF-I treatment did not affect IGFBP-4 levels but enhanced the production of IGFBP-3 by both cell types ( $p<0.05$ ). However, the response of TS fibroblasts to IGF-I was approximately half that observed in normal cells $(p<0.05)$. Altered IGF-I activity, because of reduced bioavailabilty and/or reduced sensitivity, could contribute to the need for high $\mathrm{GH}$ doses in TS and for the poor response to $\mathrm{GH}$ in some girls with TS. (Pediatr Res 70: 25-30, 2011)
\end{abstract}

$\mathrm{T}^{\mathrm{s}}$ urner syndrome (TS; complete or partial absence of an X chromosome) affects 1 in 2500 live births and is associated with pre- and postnatal growth failure (1), so that if untreated, girls with TS are $\approx 20 \mathrm{~cm}$ shorter than the normal female population at adulthood (2). Consequently, children with this condition are treated with growth hormone $(\mathrm{GH})$.

There is some controversy about whether the GH/IGF axis of children with TS is normal. Some studies have shown that secretion of GH is diminished in TS (3), although the majority have found that GH levels are normal in comparison with agematched control subjects $(4,5)$. Similarly, the data regarding IGF-I levels in TS are conflicting as both higher (3) and lower (6) than normal levels have been reported.

Regardless of endogenous GH/IGF levels, numerous studies have shown that treatment with GH has a beneficial effect on the height of children with TS (7); however, supraphysiological doses are required and the response to treatment is highly variable — determined, at least in part, by GH dose, and

Received September 10, 2010; accepted January 12, 2011

Correspondence: Melissa Westwood, Ph.D., Maternal and Fetal Health Research Centre, University of Manchester, St Mary's Hospital, Oxford Road, Manchester M13 9W, United Kingdom; e-mail: melissa.westwood@manchester.ac.uk

This research was funded by an unrestricted grant from NovoNordisk. The Group is supported by funding from the NIHR Manchester Biomedical Research Centre. age and height at the start of therapy (8) —and although treated women are taller than untreated women, their final height is more than 2 SD scores below the mean for normal women (7). These clinical data suggest that although there are no major aberrations in the levels of GH and/or IGF-I in children with TS, their cellular sensitivity to these hormones may be reduced. Indeed, it has been reported that IGF-I-stimulated degradation of LDL by monocytes isolated from children with $\mathrm{TS}$ is reduced in comparison with that of cells obtained from control subjects (9). It is also possible that in TS, impaired IGF-I action may reflect a reduction in bioavailability because fibroblast cells from children with TS have been shown to produce more IGF binding protein (IGFBP)-3-a negative regulator of IGF function-than fibroblasts from normal children (10). Consequently, this study aimed to characterize a functional response (IGFBP generation) to GH and IGF-I in fibroblasts isolated from children with TS.

\section{MATERIALS AND METHODS}

Cell culture. Fibroblast cells were isolated from skin biopsies obtained, with informed parental consent and approval from both the local NHS (Salford and Trafford) and the University of Manchester research ethics committees, from eight children with TS (confirmed by karyotype analysis) and five normal children in the prepubertal age range at time of biopsy. All cells were maintained in DMEM containing $10 \%$ FCS, $2 \mathrm{mM}$ glutamine, $50 \mathrm{IU}$ penicillin, $50 \mathrm{IU}$ streptomycin, and $2.5 \mu \mathrm{g} / \mathrm{mL}$ amphotericin $\mathrm{B}$ at $37^{\circ} \mathrm{C}, 5 \% \mathrm{CO}_{2}$.

Characterization of IGFBP production. Normal and Turner fibroblast cells were seeded at $1 \times 10^{4}$ cells/well in DMEM containing $1 \% \mathrm{FCS}$ and either $\mathrm{GH}(200 \mathrm{ng} / \mathrm{mL}$; based on dose-response experiments performed in our previous studies of human fibroblast proliferation) (11), IGF-I (100 ng/mL), $\mathrm{GH}$ and IGF-I, or no additional supplement. The cells were cultured for $7 \mathrm{~d}$ with the further addition of hormones [GH $(200 \mathrm{ng} / \mathrm{mL})$, IGF-I $(100 \mathrm{ng} / \mathrm{mL})$, or GH and IGF-I on d 2, 4, and 6; conditioned medium (CM) was harvested on $\mathrm{d} 1,3,5$, and 7 . Each treatment and time-point was analyzed in triplicate in two independent experiments on each cell line.

Western ligand blotting. The protein content of each sample of $\mathrm{CM}$ was determined, and then aliquots containing $100 \mu \mathrm{g}$ protein were subjected to trichloroacetic acid precipitation. The resulting protein pellet was resuspended in SDS loading buffer (without $\beta$-mercaptoethanol) and boiled for $5 \mathrm{~min}$. The protein in each sample was then resolved by SDS PAGE, transferred to nitrocellulose, and probed with ${ }^{125}$ I-IGF-I (12). Densitometric analysis of the scanned autoradiographs was performed using Image J software (http:// rsbweb.nih.gov/ij/).

Western immunoblotting. Samples were electophoresed and blotted as described above and then probed overnight at $4^{\circ} \mathrm{C}$ with an anti-IGFBP-3 polyclonal antibody (1:1000 dilution; Upstate, Milton Keynes, United Kingdom) followed by an anti-rabbit IgG antibody linked to horseradish peroxi-

Abbreviations: CM, conditioned medium; IGFBP, IGF binding protein; ISS, idiopathic short stature; TS, Turner syndrome 
dase (1:5000 dilution; Amersham Life Sciences, Buckinghamshire, United Kingdom) for $1 \mathrm{~h}$ at room temperature. Proteins were detected by enhanced chemiluminescence (Amersham Life Sciences).

IGFBP-3 immunoassay. The concentration of IGFBP-3 present in each sample of CM was determined using the Immulite (Siemens Healthcare, Surrey, United Kingdom) assay, which has an inter- and intra-assay coefficient of variation $(\mathrm{CV})$ of $<5.6 \%$ and $<10 \%$, respectively.

IGFBP-4 immunoassay. The samples of CM were analyzed for IGFBP-4 by using the ELISA developed by DSL (Texas), which has an inter- and intra-assay $\mathrm{CV}$ of $<5 \%$.

Characterization of GH-stimulated activation of JAK-2. Normal and Turner fibroblast cells were serum starved for $24 \mathrm{~h}$ and then incubated in the absence or presence of $\mathrm{GH}(200 \mathrm{ng} / \mathrm{mL})$ for $0,2,5,15,30$, or $60 \mathrm{~min}$. Cell lysates were prepared using RIPA buffer and after protein quantification, 30 $\mu \mathrm{g}$ of protein from each sample was diluted in SDS loading buffer containing $\beta$-mercaptoethanol, electrophoresed and then electroblotted onto nitrocellulose membranes. Activation of GH signaling pathways was assessed by probing with an antibody that specifically recognizes the phosphorylated isoform of JAK-2 (1:500; Cell Signaling Technology). Immune complexes were detected using an HRP-anti-rabbit-IgG antibody followed by enhanced chemiluminescence. An antibody that recognizes all isoforms of JAK-2 (anti-JAK-2, 1:500, Upstate) was used to control for protein loading of the gels.

Statistical analysis. The level of IGFBP-3 and IGFBP-4 present in media conditioned by fibroblasts, isolated from normal children or children with TS, and cultured with and without hormones for $7 \mathrm{~d}$ was $\log 10$ transformed and analyzed by a three-way (cell type, time, and treatment) independent ANOVA with Bonferroni post hoc testing, and then, the data obtained from each time-point/hormone combination were analyzed by a one-way analysis of covariance (ANCOVA) to control for the difference in basal hormone production by the two cell types. The reported results include the $F$-ratio (the ratio of systematic variance to unsystematic variance), the degrees of freedom from which it was calculated, and the significance value.

The fold-change (versus control) in IGFBP-3 levels induced by treatment of normal versus Turner fibroblasts for $7 \mathrm{~d}$ with GH, IGF-I, or both hormones was analyzed by Mann-Whitney $U$ test. Results were considered significant when $p<0.05$ (IGFBP-3) or $p<0.01$ (IGFBP-4) as determined by Levene's test of equality of error variances. Untransformed data are presented graphically as mean \pm SEM.

\section{RESULTS}

Fibroblasts from children with TS produce a similar IGFBP profile to cells from normal children. Ligand blot analysis of conditioned media obtained from normal and Turner fibroblast cells maintained in culture under basal conditions for $7 \mathrm{~d}$ revealed that the two cell types produce a similar profile of IGFBPs. Bands were evident at 45, 34, 30, and $24 \mathrm{kD}$ (Fig. 1A) and comparison of these proteins with the migratory pattern of recombinant human IGFBP-3 and the IGFBPs within human serum, which were included in the analysis as positive controls, suggests that both normal and Turner fibroblast cells produce IGFBPs 3, 2, 5, and 4 (Fig. 1A). IGFBP production by the individual cell lines within both the normal and Turner cell cohorts varied. However, densitometric analysis of all ligand blots suggested that both cell types predominantly produce IGFBP-3 although normal fibroblasts also produce an abundance of IGFBP-4 (Fig. $1 B$ ); consequently, these binding proteins were selected for further analysis.

Fibroblasts from children with TS produce more IGFBP-3 but similar levels of IGFBP-4 in comparison with cells from normal children. The generation of these IGFBPs, by both normal and Turner fibroblast cells, seemed to increase over the $7 \mathrm{~d}$ in culture (Fig. $1 A$ and $B$ ), which was confirmed by measuring the concentration of these binding proteins using specific immunoassays (Fig. 2 and Table 1; IGFBP-3: $p<0.05$; IGFBP-4: $p<0.01$ ). Analysis of the IGFBP-3 levels present in $\mathrm{CM}$ also revealed that in comparison with fibroblasts obtained from normal children, cells from children with TS produce significantly more IGFBP-3 under basal conditions $(p<0.05)$. IGFBP-3 is subject to proteolytic cleavage and a study of circulating IGFBP-3 found this process to be enhanced in women with TS (13). We therefore used Western immunoblotting to investigate whether the IGFBP-3 present in CM of normal and Turner fibroblasts was also fragmented. However, as shown in Fig. $2 C$, we were able to detect only intact IGFBP-3. The level of IGFBP-4 in the medium conditioned by fibroblasts from normal and TS subjects was similar ( $p=$ nonsignificant).

Fibroblasts from both normal children and children with Tuner syndrome produce IGFBP-3 in response to IGF-I but not $\boldsymbol{G H}$. We next investigated whether GH and/or IGF-I treatment alters the IGFBP profile generated by normal and Turner fibroblast cells. Western ligand blot analysis of media harvested from cells treated with GH, IGF-I, or a combination of the two hormones demonstrated that the pattern of IGFBPs produced by the two cell types was not affected by hormone treatment as IGFBP-3 and IGFBP-4 were still the most abundant IGFBPs present (data not shown). Analysis of the conditioned media by specific immunoassay revealed that only the generation of IGFBP-3 was influenced by hormone treatment ( $p<0.05$; Fig. 3 and Table 1$)$ because the level of IGFBP-4 present in media harvested from hormone-treated cells was similar to that measured in media from cells maintained under basal conditions ( $p=$ nonsignificant; Fig. 3). IGFBP-3 production was only enhanced by stimulation with
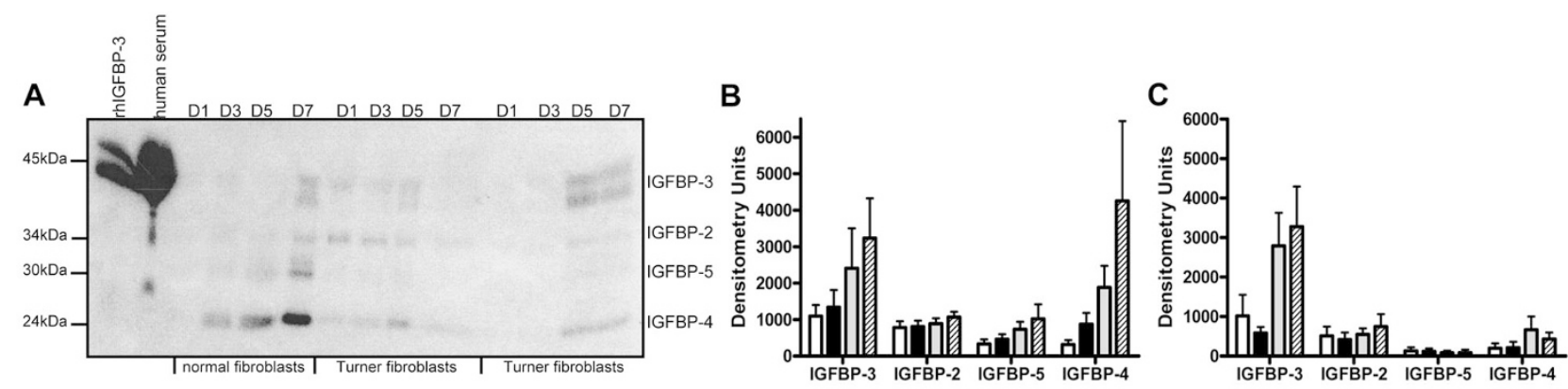

Figure 1. Normal and Turner fibroblasts produce a similar IGFBP profile. The IGFBP profile of fibroblasts from normal children $(n=5)$ and children with TS $(n=8)$ was assessed by Western ligand blotting with ${ }^{125}$ I-IGF-I. A representative blot is shown in $(A)$; human recombinant IGFBP-3 and human serum were included as positive controls. The data obtained from densitometric analysis of all blots are shown in $(B)$ (normal fibroblasts) and $(C)$ (Turner fibroblasts);

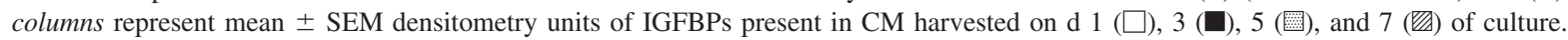




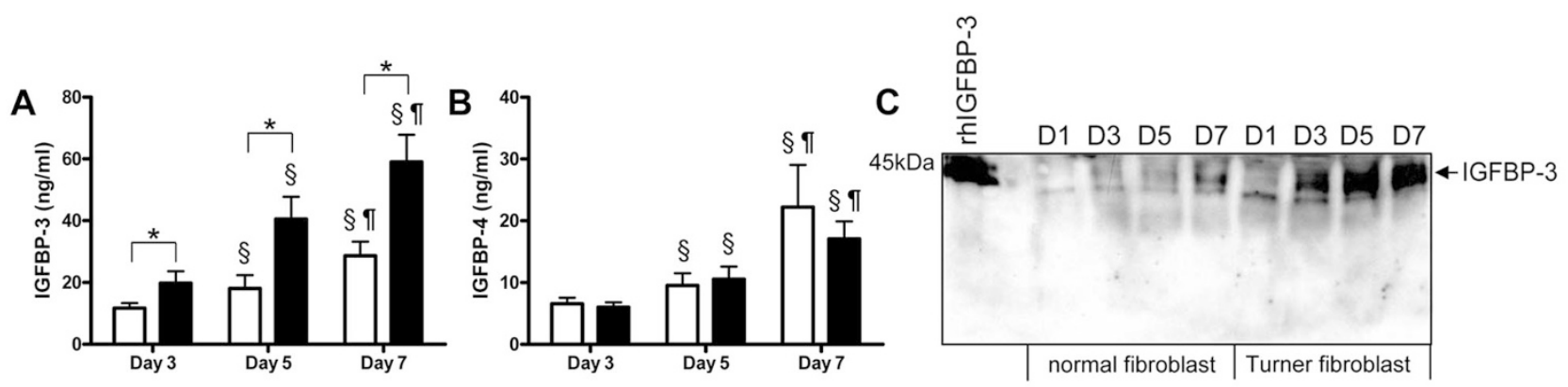

Figure 2. Turner fibroblasts produce more IGFBP-3 but a similar level of IGFBP-4 in comparison with normal fibroblasts. Media conditioned by fibroblasts from normal children and children with TS were analyzed for IGFBP-3 $(A)$ and IGFBP-4 $(B)$ by immunoassay. Data are presented as mean \pm SEM; white bars—normal fibroblasts, black bars—Turner fibroblasts. * denotes significant difference between normal and Turner fibroblasts $(p<0.05)$; $\S$ denotes significant difference in comparison with d 3 (IGFBP-3 $-p<0.05$; IGFBP-4 $-p<0.01$ ); I denotes significant differences in comparison with d 5. IGFBP-3 and IGFBP-4 levels are reported as $\mathrm{ng} / \mathrm{mL}$; data can be converted to SI units (nmol/L) by multiplying by 0.035 and 0.038 , respectively. (C) The proteolytic status of IGFBP-3 present in harvested media (100 $\mu \mathrm{g}$ total protein) was analyzed by Western immunoblotting with an anti-IGFBP-3 polyclonal antibody; a representative blot is shown. Intact recombinant human IGFBP-3 was included as a control.

Table 1. Analysis of IGFBP-3 and IGFBP-4 levels by three-way independent ANOVA

\begin{tabular}{|c|c|c|c|c|c|c|}
\hline \multirow[b]{2}{*}{ Variable } & \multicolumn{3}{|c|}{ IGFBP-3 } & \multicolumn{3}{|c|}{ IGFBP-4 } \\
\hline & $F$ & $d f$ & Sig & $F$ & $d f$ & Sig \\
\hline Cell & 27.37 & 1 & 0.00 & 3.941 & 1 & NS \\
\hline Time & 41.92 & 2 & 0.00 & 55.20 & 2 & 0.00 \\
\hline Treatment & 18.54 & 3 & 0.00 & 2.43 & 3 & NS \\
\hline Cell $\times$ Time & 0.14 & 2 & NS & 1.15 & 2 & NS \\
\hline Cell $\times$ Treatment & 0.14 & 3 & NS & 0.68 & 3 & NS \\
\hline Time $\times$ Treatment & 0.16 & 6 & NS & 0.77 & 6 & NS \\
\hline Cell $\times$ Time $\times$ Treatment & 0.18 & 6 & NS & 0.59 & 6 & NS \\
\hline
\end{tabular}

The level of IGFBP-3 and IGFBP-4 present in media conditioned by fibroblasts, isolated from normal children or children with TS, cultured with and without hormones for $7 \mathrm{~d}$ was $\log 10$ transformed and analyzed by a three-way independent ANOVA. Cell refers to normal or Turner fibroblasts; time refers to the length of culture- $\mathrm{d} 3,5$, or 7 ; treatment refers to the treatment conditions - control, GH $(200 \mathrm{ng} / \mathrm{mL})$, IGF-I $(100 \mathrm{ng} / \mathrm{mL})$, or both GH and IGF-I. $\times$ determines whether there is an interaction effect between two or more of the variables (e.g. cell $\times$ treatment determines whether treatment has a different effect in normal $v s$ TS fibroblasts). Results were considered significant when $p<0.05$ (IGFBP-3) or $p<0.01$ (IGFBP-4) as determined by Levene's test of equality of error variances.

F, F ratio; df, degrees of freedom; Sig, significance.

IGF-I (Fig. 3). The Bonferroni post hoc test revealed that the level of IGFBP-3 produced by cells treated with GH was no different to that secreted by control cells, whereas there was a 2- to 4-fold increase (depending on day) in the level of IGFBP-3 present in media conditioned by cells treated with either IGF-I or a combination of GH and IGF-I $(p<0.05)$.

The response of cells from children with TS to treatment with either IGF-I or GH plus IGF was compared with that of control cells after controlling for the difference in the basal level of IGFBP-3 produced by the two cell types. Interestingly, this analysis revealed that the Turner fibroblasts did not respond as well as control cells to stimulation with a combination of GH and IGF-I $(p<0.05)$ as even after $7 \mathrm{~d}$ in culture, there was only a 2-fold increase in the level of IGFBP-3 detected in CM, whereas IGFBP-3 levels had increased 4-fold in media conditioned by control cells (Fig. $4 ; p<0.05$ ). A similar trend was observed when cells were treated with only IGF-I. Indeed, the level of IGFBP-3 produced in response to incubation of cells with GH and IGF-I was no different to that generated by cells treated with only IGF-I, which suggests that the increase in IGFBP-3 levels observed after dual hormone treatment was primarily because of the actions of IGF-I. However, to ensure that the GH preparation used for these studies was bioactive, we used Western blotting to assess the phosphorylation status of JAK-2, the signaling molecule immediately downstream of the GH receptor. Figure 5 demonstrates that although there may be subtle differences in the tempo of activation, $\mathrm{GH}$ does stimulate phosphorylation of JAK-2 in both types of fibroblast, which suggests that these cells are capable of responding to GH. None of the hormone treatments resulted in the detection of IGFBP-3 fragments (data not shown).

\section{DISCUSSION}

Girls with TS are treated with GH to alleviate the short stature associated with this condition; however, the clinical benefit, at least in terms of growth promotion, can be disappointing despite the use of supraphysiological doses. These clinical observations along with ex vivo studies of cells isolated from affected girls $(9,10)$ have led to the hypothesis that although there are no major abnormalities in the GH/IGF axis of children with TS, cellular sensitivity to one or both of these hormones is decreased.

The importance of autocrine/paracrine IGF-I levels for growth was highlighted by the generation of mice with a liver-specific deletion of the igfl gene (14), which have normal postnatal growth despite a $75 \%$ reduction in circulating IGF-I levels. Therefore, this study sought to investigate, by assessing IGFBP generation as a marker of function, whether TS cells display an altered cellular response to GH and IGF-I.

Western ligand blotting of media conditioned by fibroblasts isolated from normal children and girls with TS revealed that both cell types produce IGFBP-3, -2, -4, and -5 , which supports the findings of a study analyzing IGFBP mRNA expression in human skin (15) and also the IGFBP profile of cell lines derived from adult human fibroblasts (16) which were found, like the fibroblasts used in this study, to predominantly produce IGFBP-3 and IGFBP-4. 

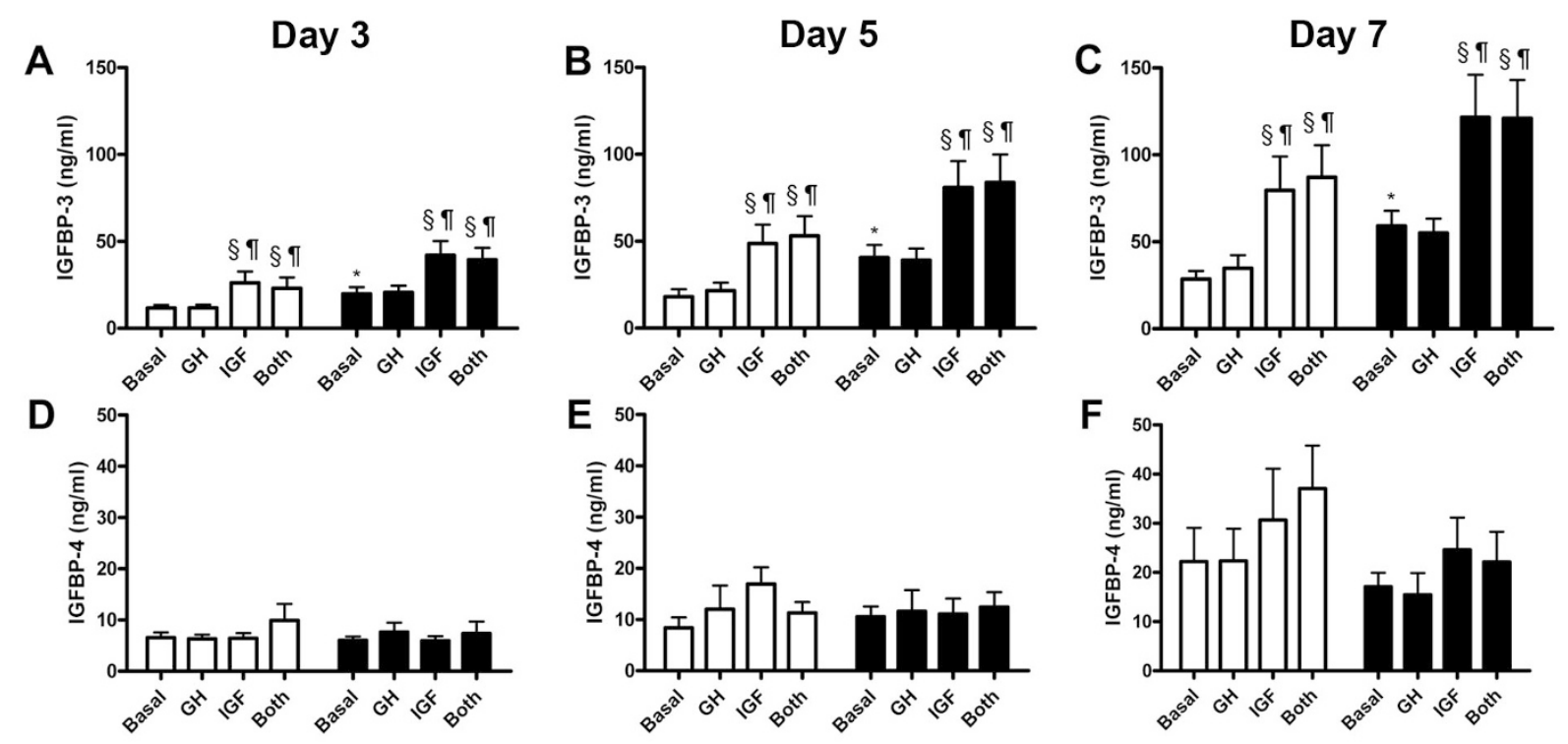

Figure 3. IGF-I, but not GH, stimulates the production of IGFBP-3 by both normal and Turner fibroblasts. Fibroblasts were cultured in the absence or presence of GH, IGF-I, or a combination of both hormones for up to $7 \mathrm{~d}$ in culture. Media was harvested on d 3 ( $A$ and $D), 5(B$ and $E$ ), and $7(C$ and $F)$ of culture and analyzed for IGFBP-3 $(A-C)$ and IGFBP-4 $(D-F)$ by immunoassay. Data are presented as mean \pm SEM; white bars-normal fibroblasts, black bars-Turner fibroblasts. * denotes significant difference between normal and Turner fibroblasts $(p<0.05)$; $\S$ denotes significant differences from untreated (basal) cells $(p<$ $0.05)$; II denotes significant differences from GH-treated cells $(p<0.05)$. IGFBP-3 and IGFBP-4 levels are reported as ng/mL; data can be converted to SI units (nmol/L) by multiplying by 0.035 and 0.038 , respectively.

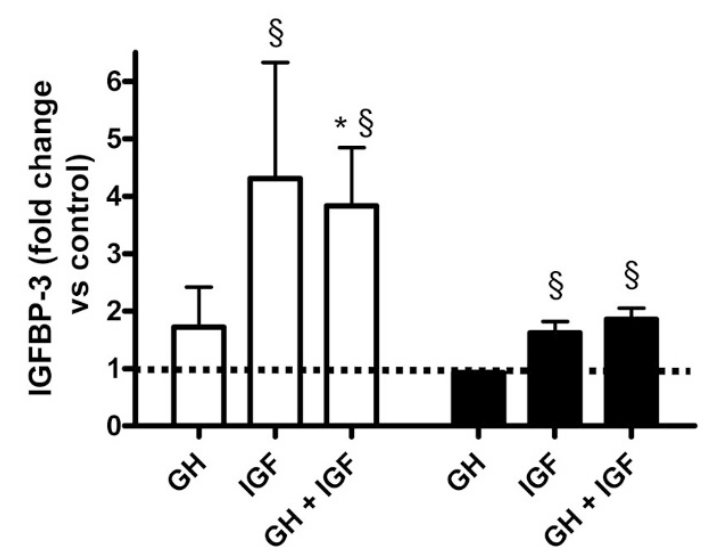

Figure 4. Turner fibroblasts do not respond as control cells to treatment with GH plus IGF-I. Fibroblasts from normal children and children with TS were cultured in the absence or presence of GH, IGF-I,or a combination of both hormones for up to $7 \mathrm{~d}$. Media harvested on $\mathrm{d} 7$ of culture was analyzed for IGFBP-3 by immunoassay. The fold change, relative to the level of IGFBP measured in the media from untreated cells, was calculated for each cell line,and data are presented as the mean fold increase for normal $(\square)$ and TS fibroblasts $(\square)$. * denotes significant difference between normal and Turner fibroblasts $(p<0.05)$; $\S$ denotes significant differences from untreated (basal) cells $(p<0.05)$.

There was marked variation in the level of IGFBP-3 and BP-4 produced by both cohorts of cells; nonetheless it was apparent that the basal production of IGFBP-3 by TS fibroblasts was significantly higher than that of normal fibroblasts, which supports previous findings (10). We investigated whether this increase in IGFBP-3 levels was countered by a change in the proteolysis of the binding protein because a study of IGFBP-3 present in the serum of adult females demonstrated increased fragmentation in TS (13). However, there was no evidence to suggest that the IGFBP-3 present within the $\mathrm{CM}$ of either normal or Turner fibroblast cells had undergone proteolysis. Interestingly, cells from children with another growth disorder, idiopathic short stature (ISS), also have enhanced IGFBP-3 production in comparison with control cells (17). The level of IGFBP-3 present in the circulation is well known to be regulated by GH $(16,18)$ and a study of normal and Turner fibroblasts reported a stimulatory, albeit nonsignificant, affect of GH on IGFBP-3 production by control cells (10). In our study, only treatment of cells with IGF-I affected the level of IGFBP-3 present in the culture media. The response of cells treated with both GH and IGF-I was similar to that of cells treated with IGF-I alone suggesting that GH does not regulate IGFBP-3 production by these fibroblasts.

We excluded the possibility that this finding was due to an inactive preparation of $\mathrm{GH}$ used for the studies by monitoring the ability of GH to phosphorylate the signaling molecule JAK-2; the GH receptor lacks intrinsic kinase activity and depends on the recruitment of JAK-2 for phosphorylation of the GH/GHR complex and subsequent activation of downstream signaling pathways (19). Consequently, GH is unable to activate JAK-2 in skin fibroblasts derived from individuals with Laron syndrome $(20,21)$. JAK-2 was present and basally active in both cell types, supporting previous observations in normal fibroblasts (20). GH stimulated the phosphorylation of JAK2 in both normal and TS cells, thereby confirming GH bioactivity; however, in the latter, active JAK-2 was still present 60 min after treatment, which suggests that the tempo of JAK-2 activation might differ between the two cell types. Recent studies have identified defects within the GH/IGF signaling cascades in individuals with growth disorders; mutations in STAT-5b result in GH insensitivity and reduced growth (22) and short stature is also associated with mutations in the gene coding for the type 1 IGF receptor (23). These are 

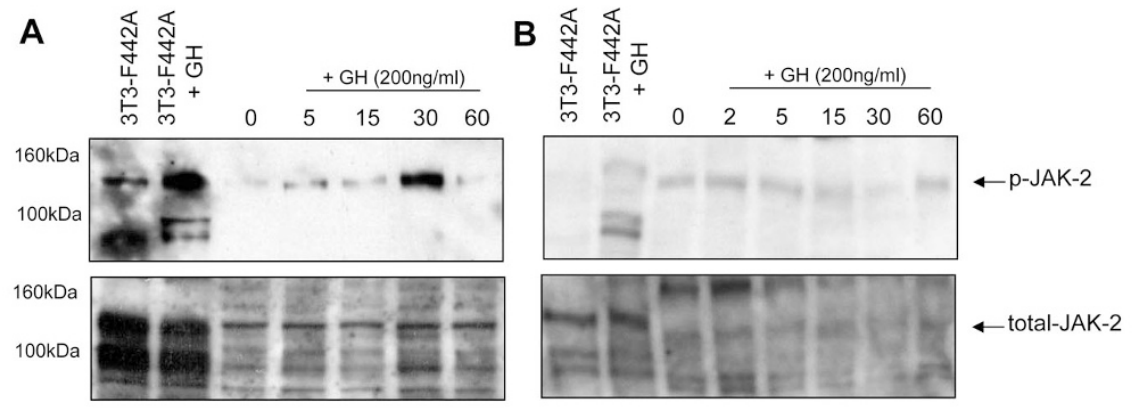

Figure 5. GH stimulates the phosphorylation of JAK-2 in fibroblast cells from both normal and Turner fibroblasts. Fibroblasts obtained from normal children $(A)$ and children with TS $(B)$ were serum starved for $24 \mathrm{~h}$ and then stimulated with $\mathrm{GH}$ for 0-60 min. Lysates were analyzed by Western blotting using antibodies that specifically recognize the phosphorylated or total isoforms of JAK-2. Lysates from 3T3F442A fibroblasts incubated in the absence or presence of $\mathrm{GH}$ were included as positive controls. severe genetic abnormalities that result in extreme phenotypes but such observations do support the hypothesis that less severe signaling defects may be associated with growth restriction in conditions such as TS.

Our data demonstrating that IGFBP-3 production is regulated by IGF-I is consistent with the findings of other in vitro $(24,25)$ and in vivo $(26,27)$ studies, and IGF-I has also been shown to stimulate IGFBP-3 in fibroblast cells isolated from individuals with ISS (17). In our study, IGF-I seemed to be more effective in normal fibroblasts because the level of IGFBP-3 produced by Turner fibroblasts, particularly when treated in combination with GH was significantly less than that produced by control cells. These findings are in contrast to the effect of fibroblasts from children with ISS, where IGF-I was hyperstimulatory (17) and suggest that in TS, the activity of autocrine/paracrine IGF is compromised. The reduced sensitivity to local IGF-I may, in part, be explained by a decrease in IGF-I bioavailability because of the increased basal IGFBP-3 production by these cells; however, our data suggest that TS cells must have a second abnormality, for example dysfunction in the signaling pathways evoked by IGF-I, because ANCOVA demonstrated that in comparison with control cells, the TS cell response to IGF-I was attenuated even after their excess IGFBP-3 production had been taken into account. Our findings support the concept of end-organ resistance to IGF-I and perhaps explain the necessity for treating girls with TS with supraphysiological doses of GH. Interestingly, in a study of children born small-for-GA, IGFBP-3 levels at age $2-3$ y were negatively related to adult height, and GH efficacy was reduced in the presence of high IGFBP-3 levels (28).

The basal production of IGFBP-4 by TS fibroblasts was similar to that of cells obtained from normal children, and the level of IGFBP-4 present in conditioned media was not affected by hormone stimulation in either cell type. Other studies have shown that IGF-I does not influence IGFBP-4 mRNA expression (29); however, there are data to suggest that IGF-I might reduce the presence of IGFBP-4 in dermal fibroblast-conditioned media $(16,25)$ by stimulating the proteolysis of this binding protein. In our study, there was no evidence of IGFBP-4 proteolysis from Western ligand blot analysis of the conditioned media obtained from cells treated with GH and/or IGF-I. However, IGFBP-3 is thought to inhibit IGF-induced proteolysis of IGFBP-4 in a manner dependent on the relative proportions of IGFBPs and the level of IGF (25); as IGF-I stimulated IGFBP-3 production by the cells used in this study, this may explain why we did not observe any IGFBP-4 proteolysis.

In summary, our data demonstrate that fibroblasts isolated from children with TS produce a similar IGFBP profile to cells from normal children, but seem to have impaired responsiveness to treatment with IGF-I. This suggests that altered autocrine/paracrine IGF bioavailability may contribute to the need for high-dose GH treatment and to the relatively poor clinical response to $\mathrm{GH}$ of some girls with TS.

Acknowledgments. We thank Dr Jenny Jones for performing the IGFBP-4 assays reported in this article.

\section{REFERENCES}

1. Saenger P 1996 Turner's syndrome. N Engl J Med 335:1749-1754

2. Rochiccioli P, David M, Malpuech G, Colle M, Limal JM, Battin J, Mariani R, Sultan C, Nivelon JL, Simonin G, Bost M, Chatelain P, Bertrand AM, Freycon R, Bouquier JJ, Pierron P 1994 Study of final height in Turner's syndrome: ethnic and genetic influences. Acta Paediatr 83:305-308

3. Zadik Z, Landau H, Chen M, Altman Y, Lieberman E 1992 Assessment of growth hormone $(\mathrm{GH})$ axis in Turner's syndrome using 24-hour integrated concentrations of $\mathrm{GH}$, insulin-like growth factor-I, plasma GH-binding activity, GH binding to IM9 cells, and GH response to pharmacological stimulation. J Clin Endocrinol Metab 75:412-416

4. Lanes R, Brito S, Suniaga M, Moncada G, Borges M 1990 Growth hormone secretion in pubertal age patients with Turner's syndrome. J Clin Endocrinol Metab 71:770-772

5. Wit JM, Massarano AA, Kamp GA, Hindmarsh PC, van Es A, Brook CG, Preece MA, Matthews DR 1992 Growth hormone secretion in patients with Turner's syndrome as determined by time series analysis. Acta Endocrinol (Copenh) $127: 7-12$

6. Massa G, Bouillon R, Vanderschueren-Lodeweyckx M 1992 Serum growth hormone (GH)-binding protein and insulin-like growth factor-I levels in Turner's syndrome before and during treatment with recombinant human GH and ethinyl estradiol. J Clin Endocrinol Metab 75:1298-1302

7. Baxter L, Bryant J, Cave CB, Milne R 2007 Recombinant growth hormone for children and adolescents with Turner syndrome. Cochrane Database Syst Rev 1:CD003887

8. Ranke MB, Lindberg A, Ferrandez-Longas A, Darendeliler F, Albertsson-Wikland K, Dunger D, Cutfield WS, Tauber M, Wilton P, Wollmann HA, Reiter EO 2007 Major determinants of height development in Turner syndrome (TS) patients treated with GH: analysis of 987 patients from KIGS. Pediatr Res 61:105-110

9. Hochberg Z, Aviram M, Rubin D, Pollack S 1997 Decreased sensitivity to insulinlike growth factor I in Turner's syndrome: a study of monocytes and T lymphocytes. Eur J Clin Invest 27:543-547

10. Barreca A, Larizza D, Damonte G, Arvigo M, Ponzani P, Cesarone A, Lo CF, Severi F, Giordano G, Minuto F 1997 Insulin-like growth factors (IGF-I and IGF-II) and IGF-binding protein-3 production by fibroblasts of patients with Turner's syndrome in culture. J Clin Endocrinol Metab 82:1041-1046

11. Freeth JS, Ayling RM, Whatmore AJ, Towner P, Price DA, Norman MR, Clayton PE 1997 Human skin fibroblasts as a model of growth hormone (GH) action in GH receptor-positive Laron's syndrome. Endocrinology 138:55-61

12. Westwood M, Gibson JM, Pennells LA, White A 1999 Modification of plasma insulin-like growth factors and binding proteins during oral contraceptive use and the normal menstrual cycle. Am J Obstet Gynecol 180:530-536

13. Gravholt CH, Frystyk J, Flyvbjerg A, Orskov H, Christiansen JS 2001 Reduced free IGF-I and increased IGFBP-3 proteolysis in Turner syndrome: modulation by female sex steroids. Am J Physiol Endocrinol Metab 280:E308-E314

14. Yakar S, Liu J-L, Stannard B, Butler A, Accili D, Sauer B, LeRoith D 1999 Normal growth and development in the adsence of hepatic insulin-like growth factor I. Proc Natl Acad Sci U S A 96:7324-7329 
15. Batch JA, Mercuri FA, Edmondson SR, Werther GA 1994 Localization of messenger ribonucleic acid for insulin-like growth factor binding proteins in human skin by in situ hybridization. J Clin Endocrinol Metab 79:1444-1449

16. Neely EK, Rosenfeld RG 1992 Insulin-like growth factors (IGFs) reduce IGFbinding protein-4 (IGFBP-4) concentration and stimulate IGFBP-3 independently of IGF receptors in human fibroblasts and epidermal cells. Endocrinology 130:985-993

17. Kamp GA, Ouwens DM, Hoogerbrugge CM, Zwinderman AH, Maassen JA, Wit JM 2002 Skin fibroblasts of children with idiopathic short stature show an increased mitogenic response to IGF-I and secrete more IGFBP-3. Clin Endocrinol (Oxf) $56: 439-447$

18. Gargosky SE, Wilson KF, Fielder PJ, Vaccarello MA, Guevara-Aguirre J, Diamond FB, Baxter RC, Rosenbloom AL, Rosenfeld RG 1993 The composition and distribution of insulin-like growth factors (IGFs) and IGF-binding proteins (IGFBPs) in the serum of growth hormone receptor-deficient patients: effects of IGF-I therapy on IGFBP-3. J Clin Endocrinol Metab 77:1683-1689

19. Hansen LH, Wang X, Kopchick JJ, Bouchelouche P, Nielsen JH, Galsgaard ED, Billestrup N 1996 Identification of tyrosine residues in the intracellular domain of the growth hormone receptor required for transcriptional signaling and Stat5 activation. J Biol Chem 271:12669-12673

20. Silva CM, Kloth MT, Whatmore AJ, Freeth JS, Anderson N, Laughlin KK, Huynh T, Woodall AJ, Clayton PE 2002 GH and epidermal growth factor signaling in normal and Laron syndrome fibroblasts. Endocrinology 143:2610-2617

21. Freeth JS, Silva CM, Whatmore AJ, Clayton PE 1998 Activation of the signal transducers and activators of transcription signaling pathway by growth hormone $(\mathrm{GH})$ in skin fibroblasts from normal and $\mathrm{GH}$ binding protein-positive Laron Syndrome children. Endocrinology 139:20-28
22. Kofoed EM, Hwa V, Little B, Woods KA, Buckway CK, Tsubaki J, Pratt KL, Bezrodnik L, Jasper H, Tepper A, Heinrich JJ, Rosenfeld RG 2003 Growth hormone insensitivity associated with a STAT5b mutation. N Engl J Med 349:1139-1147

23. Abuzzahab MJ, Schneider A, Goddard A, Grigorescu F, Lautier C, Keller E, Kiess W, Klammt J, Kratzsch J, Osgood D, Pfaffle R, Raile K, Seidel B, Smith RJ, Chernausek SD 2003 IGF-I receptor mutations resulting in intrauterine and postnatal growth retardation. N Engl J Med 349:2211-2222

24. Conover CA 1990 Regulation of insulin-like growth factor (IGF)-binding protein synthesis by insulin and IGF-I in cultured bovine fibroblasts. Endocrinology 126:3139-3145

25. Donnelly MJ, Holly JM 1996 Rhe role of IGFBP-3 in the regulation of IGFBP-4 proteolysis. J Endocrinol 149:R1-R7

26. Jørgensen JO, Blum WF, Møller N, Ranke MB, Christiansen JS 1991 Short-term changes in serum insulin-like growth factors (IGF) and IGF binding protein 3 after different modes of intravenous growth hormone $(\mathrm{GH})$ exposure in $\mathrm{GH}$-deficient patients. J Clin Endocrinol Metab 72:582-587

27. Villafuerte BC, Zhang WN, Phillips LS 1996 Insulin and insulin-like growth factor-I regulate hepatic insulin-like growth factor binding protein-3 by different mechanisms. Mol Endocrinol 10:622-630

28. de Ridder MA, Stijnen T, Hokken-Koelega AC 2008 Prediction model for adult height of small for gestational age children at the start of growth hormone treatment. J Clin Endocrinol Metab 93:477-483

29. Camacho-Hubner C, Busby WH Jr, McCusker RH, Wright G, Clemmons DR 1992 Identification of the forms of insulin-like growth factor-binding proteins produced by human fibroblasts and the mechanisms that regulate their secretion. J Biol Chem 267:11949-11956 